\title{
The prognostic value of inflammatory and vascular endothelial dysfunction biomarkers in microvascular and macrovascular complications in type $\mathbf{1}$ diabetes
}

Wartość prognostyczna markerów stanu zapalnego i markerów dysfunkcji śródbłonka naczyniowego w rozwoju powikłań mikro- i makronaczyniowych cukrzycy typu 1

\author{
Anna Wołoszyn-Durkiewicz, Małgorzata Myśliwiec
}

\author{
Department of Pediatrics, Diabetology and Endocrinology, University Clinical Center in Gdansk, Poland
}

\begin{abstract}
Type 1 diabetes mellitus (T1DM) is a chronic autoimmune disease characterised by a destruction of pancreatic $\beta$ cells, which leads to absolute insulin deficiency. Persistently high glycaemia causes vascular damage throughout the body. Microvascular complications comprise the following: nephropathy, retinopathy, and neuropathy. Macrovascular complications include coronary heart disease (CHD), which may result in myocardial infarction, cerebrovascular disease (leading to strokes), and peripheral vascular disease. The pathogenesis of vascular complications is multifactorial and is probably the combination of direct glucose-mediated endothelial damage, oxidative stress, production of sorbitol, and advanced glycation end-products. Precise understanding of these mechanisms could help clinicians to identify diabetic complications earlier and subsequently implement indispensable therapy on time. It is vital to determine biomarkers of microvascular and macrovascular complications in children affected with T1DM. Advanced glycation end-products and their receptors, adhesive molecules, pro- and anti-inflammatory cytokines, enzymes such as $\mathrm{N}$-acetyl- $\beta$-D-glucosaminidase, and growth factors are the subject of ongoing studies. Numerous biomarkers of diabetic microangiopathy are already known and may constitute therapeutic targets in the future. Unfortunately, despite substantial progress in the understanding of the processes by which microvascular and macrovascular complications develop, much effort still needs to be devoted to the matter, and further investigations are required.
\end{abstract}

Key words:

diabetes mellitus type 1, diabetic angiopathy, cytokines, cell adhesion molecules.

\section{Streszczenie}

Cukrzyca typu 1 jest przewlekłą chorobą charakteryzującą się dysfunkcją komórek $\beta$ wysp trzustki, co prowadzi do całkowitego braku wydzielania insuliny. Trwale podwyższona glikemia powoduje uszkodzenie naczyń w całym organizmie. Do powikłań mikronaczyniowych cukrzycy należą: retinopatia, nefropatia i neuropatia. Do powikłań makroangiopatycznych można zaliczyć chorobę niedokrwienną serca prowadzącą do zawału mięśnia sercowego, chorobę naczyń mózgowych mogącą skutkować udarem i chorobę naczyń obwodowych. Patogeneza powikłań naczyniowych jest wieloczynnikowa i prawdopodobnie jest wynikiem bezpośredniego działania uszkadzającego glukozy na śródbłonek naczyniowy, stresu oksydacyjnego, produkcji sorbitolu i końcowych produktów glikacji. Dokładne zrozumienie tych mechanizmów mogłoby pomóc klinicystom we wcześniejszym rozpoznawaniu powikłań cukrzycowych i następnie we wprowadzeniu wymaganej terapii w odpowiednim czasie. Określenie markerów cukrzycowych powikłań mikro- i makronaczyniowych u dzieci chorych na cukrzycę typu 1 jest niezwykle istotne. Produkty końcowej glikacji i ich receptory, cytokiny pro- i antyzapalne, enzymy, takie jak N-acetyl- $\beta$-D-glukozaminidaza oraz czynniki wzrostu, są obiektem nieustannych badań. Liczne markery mikroangiopatii cukrzycowej są już poznane i w przyszłości mogą stanowić potencjalny cel terapeutyczny. Niestety, mimo znacznego postępu w zrozumieniu procesów, które prowadzą do powstawania powikłań mikro- i makronaczyniowych cukrzycy, wciąż dalsze badania są konieczne.

\section{Słowa kluczowe:}

cukrzyca typu 1, angiopatia cukrzycowa, cytokiny, cząsteczki adhezyjne. 


\section{Introduction}

Type 1 diabetes mellitus (T1DM) is a chronic autoimmune disease characterised by destruction of pancreatic $\beta$ cells, which consequently leads to absolute insulin deficiency [1]. The etiopathology of the disease is still not fully understood. Type 1 diabetes mellitus is caused by a combination of different factors, in particular, exposure to environmental triggers, genetic susceptibility or immunological dysregulation [2]. The incidence rate of T1DM is steadily increasing. According to an International Diabetes Federation (IDF) report 1,106,200 children and adolescents under 20 years old are affected by T1DM worldwide [3]. Patients suffering from T1DM are prone to develop complications, which worsen the quality of life and may even become life-threatening. Persistently high glycaemia causes vascular damage throughout the body. Microvascular complications comprise the following: nephropathy, retinopathy, and neuropathy [3, 4]. Macrovascular complications include coronary heart disease (CHD), which may result in myocardial infarction, cerebrovascular disease, leading to strokes, and peripheral vascular disease [5-7]. The pathogenesis of vascular complications is multifactorial and is probably the combination of direct glucose-mediated endothelial damage, oxidative stress, production of sorbitol, and advanced glycation end-products (AGEs) [4].

\section{Microvascular and macrovascular complications in type 1 diabetes mellitus}

Diabetic nephropathy is defined as a constant proteinuria above $500 \mathrm{mg} / 24 \mathrm{~h}$ or albuminuria greater than $300 \mathrm{mg} / 24 \mathrm{~h}$. Microalbuminuria is confirmed by finding two or three samples abnormal during 3-6 months [8]. It is a very important marker of glomerular alteration. Microalbuminuria provides the first clinical evidence for diabetic nephropathy and is a predictor of its progression [9, 10]. However, researchers emphasise the fact that, despite the improvement of glycaemic control, in a certain percentage of patients, microalbuminuria constitutes an advanced, practically irreversible stage of microangiopathy [11]. Furthermore, the relatively frequent failure of angiotensin-converting-enzyme inhibitor (ACEI) treatment has been revealed $[11,12]$. In a study conducted on the paediatric population, microalbuminuria was diagnosed in $25.7 \%$ of patients after 10 years of the disease and in as many as $50.7 \%$ after 19 years [13]. Nephropathy is the major culprit responsible for morbidity and mortality in young adolescents with T1DM. Thus, early recognition of nephropathy and implementation of treatment is crucial in the prevention of endstage renal failure. Moreover, regular follow-up is essential to capture the progression to albuminuria or regression to normoalbuminuria [8].

According to literature data, microalbuminuria indicates not only the existence of nephropathy, but also is a manifestation of general capillary blood vessel damage in other organs of the body, including the eyes [14].
Diabetic retinopathy is the most frequent cause of blindness in diabetic patients [4]. The prevalence of retinopathy varies from $50 \%$ to $90 \%$ after 10 and $20-30$ years of the disease, respectively. Adolescents are more vulnerable to develop vision-threatening stages of retinopathy than adults. Therefore, it is vital to perform an ophthalmological examination regularly. It is recommended to begin screening for diabetic retinopathy from age 11 years, with two to five years diabetes duration [8]. Treatment may be implemented only in advanced phases of the disease. In its early stages patients are encouraged to pay greater attention to the control of risk factors such as hyperglycaemia and hypertension [15].

Researchers underline the fact that subclinical changes of retinal vessels, such as disrupted blood-retina barrier and increased retinal blood flow, may precede the first clinical signs [12]. New circulating biomarkers could enable the detection of subclinical disease and may be helpful in monitoring the progression of retinopathy [15].

Furthermore, diabetes may affect the somatic and autonomic nervous system. Diabetic neuropathy is recognised in $<10 \%$ to $27 \%$ of cases in the paediatric population [8]. Researchers have demonstrated an increased prevalence of peripheral nerve abnormalities during the years 1990-2002, whereas the rate of retinopathy and microalbuminuria declined [16]. Interestingly, according to other studies, proper control of type 1 diabetes leads to decreased retinopathy and nephropathy, but also to a lower rate of neuropathy $[17,18]$. According to ISPAD guidelines, screening for neuropathy should start from age 11 years, with two to five years diabetes duration [8]. It is diagnosed on the basis of presented symptoms and physical examination [4]. Physicians diagnose neuropathy by exclusion, and even if the symptoms are present, less than one third of doctors recognise diabetic neuropathy or even discuss the matter with patients [12]. It is worth mentioning that the most frequent form of neuropathy, distal symmetrical sensorimotor neuropathy, is asymptomatic in almost $50 \%$ of cases [4]. The mortality and morbidity of cardiovascular disease (CVD) are significantly higher in diabetic patients than in the general population. Diabetic patients are 2-4 times more predisposed to developing coronary disease $[6,8]$. Atherosclerosis, ensuing in narrowing of arterial walls throughout the body, constitutes the central pathological mechanism in macrovascular disease. It is caused by chronic inflammation and injury to the arterial wall in the peripheral or coronary vascular system $[5,19]$. Atherosclerotic changes are reported in childhood and adolescence by measuring intimamedia thickness in intravascular ultrasound in T1DM patients [8] Hypertension and dyslipidaemia frequently coexist in individuals affected with diabetes [6]. Hypertension plays a more important role in coronary vascular disease development in diabetic patients than in healthy individuals. Cholesterol is a major culprit in the initiation and progression of atherosclerosis. Hence, screening of blood pressure and lipids is essential. According to ISPAD guidelines, blood pressure measurement should be carried out annually and lipid profile assessment is obligatory every two years [8]. The ADA recommends the evaluation of all the cardiovascular risk factors regularly, at least annually [7]. 


\section{Biomarkers of micro- and macrovascular complications in type 1 diabetes mellitus}

For nearly two decades researchers have been endeavouring to determine biomarkers of microvascular and macrovascular complications in children with type 1 diabetes. Advanced glycation end-products (AGEs) and their receptors, adhesive molecules, pro- and anti-inflammatory cytokines, growth factors, or enzymes, such as $\mathrm{N}$-acetyl- $\beta$-D-glucosaminidase (NAG), are the subject of ongoing studies. The correlation of inflammation, endothelial dysfunction, and hypercoagulability plays an important role in the development of vascular complications [20]. A new diagnostic tool could be useful in early detection of microangiopathy, and thereby it could allow implementation of treatment on time. It has been stated that retinal and renal alterations in children with T1DM may take place in the first years of the disease, and at that time the changes are probably reversible. Thus, during the first years of the disease is the most convenient time to take appropriate measures and avoid the development of irreversible complications [11].

\section{Advanced glycation end products and their receptors}

Advanced glycation end products play a vital role in the pathogenesis of diabetic retinopathy, nephropathy, neuropathy, and cardiomyopathy. They also constitute an important risk factor for other disorders, such as rheumatoid arthritis, osteoporosis, and aging. They are formed by glycation of proteins, which takes place during a long-standing hyperglycaemic state. Advanced glycation end products bind to the plasma membrane receptor for AGEs (RAGE) and entail an alteration of gene expression and intracellular signalling. Due to this interaction, pro-inflammatory cytokines, like interleukin $1 \alpha(\mathrm{IL}-1 \alpha), \mathrm{IL}-6$, or tumour necrosis factor $\alpha(\mathrm{TNF}-\alpha)$, adhesion molecules, such as intercellular adhesion molecule 1 (ICAM-1) and vascular cell adhesion molecule 1 (VCAM-1), and free radicals are released. This process enhances, in turn, inflammation and oxidative stress [21]. Researchers have demonstrated the prognostic value of AGEs in predicting the prevalence of diabetic microangiopathy, unlike RAGE levels [14]. Wada et al. found elevated AGE serum levels in peripheral nerves obtained from diabetic patients [22]. According to literature data, several AGEs are good biochemical markers for the early detection of diabetic retinopathy and may be used as a warning factor in the pre-proliferative stage of this complication [15]. In addition, AGE-RAGE interaction has been proven to be one of the mechanisms responsible for diabetic neuropathy development [23]. Experimental studies point to the fact that AGEs, acting directly as well as via receptor-mediated mechanisms, enhance the development of macrovascular diseases [6]. Moreover, it has been assumed that soluble forms of RAGE, acting as decoys for RAGE, may have a protective role in inflammation in atherosclerosis in T1DM patients [24]. Inhibition of AGE formation and the blocking of RAGEs may contribute to the prevention of diabetic complications [21]. It has been shown that linagliptin, an inhibitor of dipeptidyl peptidase-4 (DPP-4), blocks renal damage in type 1 diabetic rats by suppressing the AGE-RAGE axis [25].

\section{Pro- and anti-inflammatory cytokines}

Inflammatory cytokines, especially TNF- $\alpha$, are also involved in development of diabetic complications. Tumour necrosis factor $\alpha$ interacts with immune system cells and leads to the secretion of other cytokines. Numerous studies have shown that serum rates of TNF- $\alpha$ are elevated in diabetic patients affected with microangiopathy $[14,20,23,26-30]$. A group of researchers reported the highest prognostic value of TNF- $\alpha$ in predicting the occurrence of microvascular complications in comparison to 12 other studied parameters, such as AGEs or VEGF [14]. In another study, a correlation between TNF- $\alpha$ activity and the degree of renal damage was suggested [26].

In addition, TNF- $\alpha$ plays an important role in the process of atherosclerosis and seems to be involved in CHD by affecting lipid metabolism, insulin resistance, and endothelial function. Vendrell et al. reached the conclusion that -308 TNF- $\alpha$ gene polymorphism predisposes to CHD development and may become an useful predictive marker for CHD in type 2 (T2DM) diabetic women [31].

What is more, it has been stated that TNF- $\alpha$ and $I L-12$ equilibrium is a prerequisite for diabetes type 1 free from late complications in the paediatric population [32]. Another study revealed that $\mathrm{IL}-12$ predominance might prevent or postpone nephropathy development; however, it does not protect from retinopathy [33].

Diabetic patients suffering from vascular complications also present an elevated rate of serum IL-6 [20, 30]. Interleukin 6 plays a key role in CVD pathogenesis; thus, reduction of its concentration may have a cardioprotective effect [34]. It is worth noting that IL-6 - 174 GG genotype may have beneficial potential in decreasing the risk of diabetic retinopathy and nephropathy, whereas 174 - CC genotype indicates the higher susceptibility to T1DM [35].

In addition, raised levels of inflammatory cytokines IL-1 $\beta$, IL-6, IL-8, IL-17A, and TNF- $\alpha$ were reported in aqueous humour of patients with diabetic retinopathy. Researchers concluded that the higher levels of these cytokines might be associated with the earlier appearance of retinal complications [36].

Furthermore, increased IL-1, IL-6, TNF- $\alpha$, and transforming growth factor $\beta$ (TGF- $\beta$ ) concentrations are associated with the progression of nerve degeneration in diabetic neuropathy. It has been demonstrated that these cytokines affect glial cells and neurons. Although IL-6 or TNF- $\alpha$ seem to be involved in the pathogenesis of diabetic neuropathy, they are probably not responsible for the development of peripheral neuropathic pain [37].

The mechanisms by which pro-inflammatory cytokines cause $\beta$-cell demise are roughly elucidated. Therefore, attention is paid to the cytoprotective role of anti-inflammatory molecules 
such as $\mathrm{IL}-4, \mathrm{IL}-10, \mathrm{IL}-13$, and especially to the recently discovered IL-35 [38-40]. A large body of evidence indicates that functional polarisation of T-helper lymphocytes towards Th1 cells is involved in T1DM development. Peripheral blood mononuclear cells obtained from T1DM patients and their first-degree relatives establish a decreased anti-inflammatory cytokine secretion. Furthermore, it has been proven that administration of cytokines secreted from Th2 lymphocytes, such as IL-4, IL-10, and $\mathrm{IL}-13$, has a protective potential against diabetes progression in rodents. This novel immunotherapeutic strategy allows the onset of spontaneous diabetes to be delayed and reduces its prevalence in non-obese diabetic (NOD) mice [38]. Another group of researchers reported a decrease of IL-10 levels in T1DM patients and came to the conclusion that there was a correlation of higher secreting activity of $\mathrm{IL}-10$ and protection against late diabetic complications [26]. Moustafa et al. showed the decrease in IL-10 contents along with increased IL-6 levels in streptozotocininduced diabetic rats [41]

Recently, considerable efforts have been invested to investigate the therapeutic potential of IL-35, a newly discovered inhibitory cytokine. It has been demonstrated that IL-35 expression in $\beta$-cells protects NOD mice against autoimmune diabetes. It highlights the possibility of IL-35 use to treat T1DM $[39,40]$.

It has been revealed that IL-37, a newly discovered antiinflammatory cytokine, belonging to the IL-1 family, may have a protective effect in the process of the vascular calcification and atherosclerosis in diabetic patients [42]. Moreover, it has been proven that individuals with $\mathrm{CHD}$ present decreased levels of cytokines IL-35, IL-10, and TGF-1 [43].

\section{Growth factors}

Vascular endothelial growth factor (VEGF), involved in vasculo- and angiogenesis, seems to be another promising biomarker of diabetic microangiopathy. VEGF serum levels are increased in T1DM patients, and they are additionally elevated along with the longer duration of the disease and in children with microvascular complications like retinopathy and nephropathy [14, 44-48]. Moreover, Myśliwiec et al. underlined the fact that VEGF concentrations correlate with the stage of retinopathy; therefore, it may serve as a prognostic marker of diabetic retinopathy development. In addition, intravitreal injections of anti-VEGF agents are currently used in the treatment of visionthreatening stages of retinopathy, enabling the reduction of the rate of visual loss. On the other hand, the reduction of VEGF epidermal expression has been observed in T1DM patients with neuropathy [49]. Current studies indicate the protective role of VEGF-induced angiogenesis of vasa nervorum in diabetic neuropathy [50].

Sasso et al. showed increased myocardial mRNA and protein expression of VEGF along with decreased mRNA and protein expression of VEGF receptors in diabetic patients with chronic $\mathrm{CHD}$ in comparison with non-diabetic ischaemic patients [51].
Another biomarker of microangiopathy taken into account is transforming growth factor $\beta 1$ (TGF- $\beta 1$ ). It is responsible for cellular processes such as proliferation, differentiation, migration, and survival. In addition, it plays an essential role in physiological processes, including embryonic development, angiogenesis, and wound healing. This TGF- $\beta 1$ isoform establishes the strongest relationship with tissue fibrosis $[52,53]$. Studies point to the fact that TGF- $\beta 1$ serum concentrations are elevated in patients with T1DM; moreover, patients affected by microvascular complications present higher TGF- $\beta 1$ levels than patients without microangiopathy. It has been demonstrated that TGF- $\beta 1$ concentrations correlate with the severity of microvascular complications and the duration of diabetes. Increased TGF- $\beta 1$ activity has been revealed also in urine of diabetic patients and in vitreous humour of T1DM adults [53, 54]. Zyiadeh et al. demonstrated the prevention of glomerulosclerosis and renal insufficiency, resulting from T2DM, by using an anti-TGF $\beta$ antibody in diabetic mice, whereas Voelker et al. did not prove the efficacy of TGF- $\beta 1$ monoclonal antibody therapy in patients affected by T1DM and T2DM $[55,56]$.

Although TGF- $\beta 1$ was thought to be a pro-atherogenic factor for many years, recent studies have shown that, in reality, it seems to limit the atherosclerosis by modulating a number of processes such as inflammatory response or the accumulation of lipids in the vessel wall $[57,58]$. The effect of increased TGF $\beta 1$ levels in diabetics on atherogenesis is not fully elucidated, and further investigations are necessary. A group of researchers has proven that simvastatin may have a therapeutic role in atherosclerosis in patients affected by T2DM diabetes. Simvastatin therapy results in increased expression of TGF- $\beta 1$ and decreased expression of VEGF [59]. Yang et al., on the other hand, have highlighted the fact that TGF- $\beta 1$ is a potent activator of proteoglycan synthesis, which entails increased binding to LDL. Blocking growth factor actions on proteoglycan synthesis may constitute a potential therapeutic target [60].

\section{$\mathrm{N}$-acetyl- $\beta$-D-glucosaminidase}

Furthermore, evidence is mounting that disorders of glycoprotein and glycosaminoglycan metabolism, including NAG enzyme, are involved in the development of diabetic retinopathy and nephropathy. It has been shown that T1DM patients present higher concentrations of NAG and its A and B isoforms in serum and urine than healthy individuals. Mysliwiec et al. proved that children affected with retinopathy displayed higher levels of NAG and its isoforms in urine in comparison to juvenile patients without retinopathy. NAG, isoform $A$ and $B$ levels in serum were elevated as well; however, the difference was not statistically significant [26]. Furthermore, Vaidya et al. demonstrated that low NAG concentrations were associated with the regression of microalbuminuria in T1DM patients. Moreover, it has been stated that the appearance of the detectable serum TNF- $\alpha$ activity in T1DM children, presenting no sign of diabetic retinopathy, nephropathy, and no microalbuminuria, with the concomitant increase of NAG and its isoforms levels in serum 
and urine, might predict prompt occurrence of these complications [29]. Vaidya et al. found that low NAG concentrations were associated with the regression of microalbuminuria in T1DM patients [61]. In addition, it was revealed that increased urinary NAG levels are associated with the prevalence of cardiovascular autonomic neuropathy in patients with T1DM, and NAG activity correlates positively with its severity [62]. A relationship between elevated urinary NAG levels and carotid artery atherosclerosis in T1DM and T2DM patients has been observed as well $[63,64]$.

\section{Cell adhesion molecules}

In view of currently available studies, cell adhesion molecules (CAMs) seem to play an important role in the pathogenesis of vascular complications. Cell adhesion molecules take part in cell growth, differentiation, cell junction formation, or cell polarity as well as in leukocyte activation, circulation, or accumulation in inflammatory locations. They initiate the process of atherosclerosis by triggering the attachment of monocytes and lymphocytes to endothelial cells [65]. The majority of CAMs belong to one of the following families: integrins, selectins, cadherins, and immunoglobin superfamily (IgSF) molecules. The activity of intercellular adhesion molecule 1 (ICAM-1), present on leukocytes and endothelial cells, may be increased by a number of cytokines [66]. Soluble forms of ICAM-1 (sICAM-1) constitute a biomarker of endothelial damage and inflammation [67]. Elevated levels of SICAM-1 are found in autoimmune conditions, including T1DM $[65,66]$. Increased ICAM-1 concentrations in retinal tissue have been shown in patients with diabetic retinopathy [68]. A study conducted on a group of African Americans with T1DM revealed that sICAM-1 levels were associated with the elevated risk of progression of normoalbuminuria or microalbuminuria to overt albuminuria [69]. Zhou et al. proved that ICAM-1 levels were higher in patients with neuropathy in comparison to non-neuropathic individuals [37]. In addition, ICAM-1 may constitute a strong CVD predictor in diabetes [70].

Vascular cell adhesion molecule 1 (VCAM-1) is a member of the slgF family and displays a potent role in angiogenesis; hence, it seems to be a major culprit in the development of retinopathy [66]. Blum et al. reported increased concentrations of soluble forms of VCAM-1 (sVCAM-1) concurrently with elevated severity of retinopathy [71]. Soedamah-Muthu et al. demonstrated a positive correlation between the activity of sVCAM-1 and diabetic complications like retinopathy, microand macroalbuminuria, and CVD [72]. The role of sVCAM-1 in predicting CVD is contradictory. A number of studies failed to reveal a strong positive relationship between SVCAM-1 levels and CVD [72]. Moreover, Jude et al. did not find a correlation between SVCAM-1 and macrovascular disease; however, the study group in this research was small [70]. Conversely, in the Hoorn Study a strong independent relation of SVCAM-1 level and seven-year CVD mortality in type 2 diabetic patients was demonstrated [72]. There is scarce evidence confirming the re- lationship between VCAM-1 concentrations and diabetic neuropathy [73].

The family of selectins consists of E-selectin, P-selectin, and L-selectin. E-selectin, expressed on endothelial cells, is up-regulated by cytokines like TNF or IL-1 $\beta$. Its soluble forms (sE-selectin) have been proven to be increased in some disorders, for example atherosclerosis, T1DM, and T2DM diabetes [66]. Glowinska et al. showed the relationship between increased sE-selectin concentrations and T1DM, whereas no correlation with T1DM was found for SP-selectin and SL-selectin levels [65]. Other research points towards the positive correlation between sE-selectin levels and retinopathy, nephropathy, and CVD [54, 71, 74, 75]. However, the role of sE-selectin in prediction of cardiovascular complications in diabetes is not fully elucidated. According to two prospective studies, its increased levels were not associated with CHD [72]. On the other hand, in the study carried out on a group of children and adolescents with T1DM, a positive correlation between sE-selectin levels and intima-media thickness (IMT) of carotid arteries, and significant negative correlation between sE-selectin and flow mediated dilation (FMD) of the brachial artery was found. Impaired brachial artery dilation and elevated IMT are biophysical proof of structural changes in the vessels [76]. What is more, T2DM patients with peripheral arterial disease present increased sE-selectin levels [77]. Moreover, Lopes-Virella et al. stated that sE-selectin seems to be a good predictor of macroalbuminuria [78]. Research indicates that levels of adhesion molecules like ICAM-1, P-selectin, and E-selectin are associated with neuropathy [37, 79]. In addition, patients presenting painful neuropathy have higher sE-selectin concentrations [37]. Conversely, Fatthollahi et al. reported lower levels of sE-selectin in T1DM patients than in a control group. Sasongko et al. have not revealed any significant association between T1DM and adhesion molecules such as SVCAM-1, sICAM-1, and sE-selectin.

\section{Conclusions}

In conclusion, a wide range of studies are conducted all over the world to broaden the knowledge of diabetic microangiopathy and macroangiopathy pathogenesis. The precise comprehension of these mechanisms could help clinicians to identify diabetic complications earlier and subsequently implement indispensable therapy on time. Numerous biomarkers of diabetic microangiopathy are already known, and they may constitute therapeutic targets in the future. Unfortunately, despite substantial progress in the understanding of the processes by which microvascular and macrovascular complications develop, still a great deal of effort is needed. It should be noted that there are very few studies considering the pathogenesis of macrovascular complications in diabetic patients, and the vast majority of these focused on the group of adults affected with T2DM. It is crucial to carry out further investigations. Currently the intensive treatment of hyperglycaemia and improvement of glycometabolic control are still the most effective strategies to stem the development of complications [81]. 


\section{References}

1. American Diabetes Association. 2. Classification and diagnosis of diabetes: Standards of Medical Care in Diabetes - 2018. Diabetes Care 2018; 41 (suppl.1): 13-27. doi: 10.2337/dc18-S002

2. Acharjee S, Ghosh B, Al-Dhubiab BE, et al. Understanding type 1 diabetes: Etiology and models. Can J Diabetes 2013; 37: 269-276. doi: 10.1016/j.jcjd.2013.05.001

3. Ogurtsova K, da Rocha Fernandes JD, Huang Y, et al. IDF Diabetes Atlas: Global estimates for the prevalence of diabetes for 2015 and 2040. Diabetes Res Clin Pract 2017; 128: 40-50. doi: 10.1016/j. diabres.2017.03.024

4. Khalil H. Diabetes microvascular complications - A clinical update. Diabetes Metab Syndr 2017; 11: 133-139. doi: 10.1016/j. dsx.2016.12.022

5. Himaja J, Daniel NG, Kurian L, et al. Assessment of prevalence and complications of type II diabetes. EJBPS 2017; 4: 418-428.

6. Holt RI, Cockram CS, Flyvbjerg A, et al. Textbook of Diabetes. 5 ed. Chichester: Wiley Blackwell, 2017.

7. Shubrook J, Butts A, Chamberlain JJ, et al. Standards of medical care in diabetes -2017 abridged for primary care providers. Clin Diabetes 2017; 35: 5-26. doi: 10.2337/cd16-0067

8. Donaghue KC, Marcovecchio ML, Wadwa RP, et al. ISPAD clinical practice consensus guidelines 2018: microvascular and macrovascular complications in children and adolescents. Pediatr Diabetes 2018; 19 (suppl. 2): 262-274. doi: 10.1111/pedi.12742

9. Uwaezuoke SN. The role of novel biomarkers in predicting diabetic nephropathy: A review. Int J Nephrol Renovasc Dis 2017; 10: 221 231. doi: $10.2147 / / J N R D . S 143186$

10. Bouvet BR, Paparella CV, Arriaga SMM et al. Evaluation of urinary $\mathrm{N}$-acetyl-beta-D glucosaminidase as a marker of early renal damage in patients with type 2 diabetes mellitus. Arq Bras Endocrinol Metabol 2014; 58: 798-801.

11. Mysliwiec M. Prognostic significance of immunologic and biochemical markers at the early stage of diabetic nephropathy and retinopathy development in children. Annales Academiae Medicae Gedanensis XXXVIII suppl. 2, habilitation, Gdańsk 2008.

12. Barrett EJ, Liu Z, Khamaisi M, et al. Diabetic microvascular disease: An endocrine society scientific statement. J Clin Endocrinol Metab 2017; 102: 4343-4410. doi: http://dx.doi.org/10.1590/00042730000003010

13. Amin R, Widmer B, Prevost AT, et al. Risk of microalbuminuria and progression to macroalbuminuria in a cohort with childhood onset type 1 diabetes: Prospective observational study. BMJ 2008; 336: 697. doi: 10.1136/bmj.39478.378241.BE

14. Zorena K, Kula M, Malinowska E, et al. Threshold serum concentrations of tumour necrosis factor alpha (TNF $\alpha$ ) as a potential marker of the presence of microangiopathy in children and adolescents with type 1 diabetes mellitus (T1DM). Hum Immunol 2013; 74: 7581. doi: 10.1016/j.humimm.2012.10.002

15. Simó-Servat O, Simó R, Hernández C. Circulating Biomarkers of Diabetic Retinopathy: An Overview Based on Physiopathology. J Diabetes Res 2016; 2016: 5263798. doi: 10.1155/2016/5263798

16. Mohsin F, Craig ME, Cusumano J, et al. Discordant trends in microvascular complications in adolescents with type 1 diabetes from 1990 to 2002. Diabetes Care 2005; 28: 1974-1980.
17. Downie E, Craig ME, Hing S, et al. Continued reduction in the prevalence of retinopathy in adolescents with type 1 diabetes: Role of insulin therapy and glycemic control. Diabetes Care 2011; 34: 2368-2373. doi: https://doi.org/10.2337/diacare.28.8.1974

18. Copenhaver M, Hoffman RP. Type 1 diabetes: where are we in 2017? Transl Pediatr 2017; 6: 359-364. doi: 10.21037/tp.2017.09.09

19. Fowler MJ. Microvascular and macrovascular complications of diabetes. Clin Diabetes 2011; 29: 116-122.

20. Domingueti CP, Dusse LM, Carvalho MD, et al. Diabetes mellitus: The linkage between oxidative stress, inflammation, hypercoagulability and vascular complications. J Diabetes Complicat 2016; 30: 738-745. doi: 10.1016/j.jdiacomp.2015.12.018

21. Singh VP, Bali A, Singh N, et al. Advanced glycation end products and diabetic complications. Korean J Physiol Pharmacol 2014; 18 : 1-14. doi: 10.4196/kjpp.2014.18.1.1

22. Wada R, Yagihashi S. Role of advanced glycation end products and their receptors in development of diabetic neuropathy. Ann NY Acad of Sci 2005; 1043: 598-604. doi:10.1196/annals.1338.067

23. Shakeel M. Recent advances in understanding the role of oxidative stress in diabetic neuropathy. Diabetes Metab Syndr Clin Res Rev 2015; 9: 373-378. doi: 10.1016/j.dsx.2014.04.029

24. Heier M, Margeirsdottir HD, Gaarder M, et al. Soluble RAGE and atherosclerosis in youth with type 1 diabetes: A 5-year follow-up study. Cardiovasc Diabetol 2015; 14: 126. doi: 10.1186/s12933015-0292-2

25. Nakashima S, Matsui T, Takeuchi M, et al. Linagliptin blocks renal damage in type 1 diabetic rats by suppressing advanced glycation end products-receptor axis. Horm Metab Res 2014; 46: 717-721. doi: 10.1055/s-0034-1371892

26. Myśliwiec M, Zorena K, Balcerska A, et al. The activity of N-acetylbeta-d-glucosaminidase and tumor necrosis factor-alpha at early stage of diabetic retinopathy development in type 1 diabetes mellitus children. Clin Biochem 2006; 39: 851-856. doi: 10.1016/j.clinbiochem.2006.03.013

27. Mysliwiec M, Zorena K, Balcerska A, et al. Does tumor necrosis factor-alpha preceed occurrence of microalbuminuria in type 1 diabetes mellitus children? Exp Clin Diabetol 2006; 6: 131-136.

28. Zorena K, Mysliwiec M, Balcerska A, et al. Tumor necrosis factoralpha is a risk factor of retinopathy in children with poorly controlled type 1 diabetes mellitus. Exp Clin Diabetol 2006; 5: 272-276.

29. Mysliwiec M, Balcerska A, Zorena K, et al. Selected immunologic and biochemical risk factors of the retinopathy and nephropathy development in children with diabetes mellitus type 1. Endokrynol Diabetol Chor Przemiany Materii Wieku Rozw 2006; 12: 269-273. doi:

30. Zorena K, Myśliwska J, Myśliwiec M, et al. Relationship between serum levels of tumor necrosis factor-alpha and interleukin- 6 in diabetes mellitus type 1 children. Cent J Immunol 2007 (suppl. 2): 292-295.

31. Vendrell J, Fernandez-Real JM, Gutierrez C, et al. A polymorphism in the promoter of the tumor necrosis factor- $\alpha$ gene $(-308)$ is associated with coronary heart disease in type 2 diabetic patients. Atherosclerosis 2003; 167: 257-264.

32. Zorena K, Myśliwska J, Myśliwiec M, et al. Interleukin-12 and tumour necrosis factor- $\alpha$ equilibrium is a prerequisite for clinical course free from late complications in children with type 1 diabetes mellitus. Scand J Immunol 2008; 67: 204-208. doi: 10.1111/j.13653083.2007.02054.x 
33. Zorena K, Myśliwska J, Myśliwiec M, et al. Interleukin 12 as an antiangiogenic mediator in type 1 diabetic children. Pediatr Endocrinol Diabetes Metab 2007; 13: 27-31.

34. Yudkin JS, Kumari M, Humphries SE, et al. Inflammation, obesity, stress and coronary heart disease: Is interleukin-6 the link? Atherosclerosis 2000; 148: 209-214.

35. Myśliwska J, Zorena K, Myśliwiec M, et al. The -174GG interleukin-6 genotype is protective from retinopathy and nephropathy in juvenile onset type 1 diabetes mellitus. Pediatr Res 2009; 66: 341-345. doi: 10.1203/PDR.0b013e3181b1bd05

36. Feng $\mathrm{S}, \mathrm{Yu} \mathrm{H}, \mathrm{Yu} \mathrm{Y}$, et al. Levels of Inflammatory Cytokines IL-1 $\beta$, IL-6, IL-8, IL-17A, and TNF- $\alpha$ in Aqueous Humour of Patients with Diabetic Retinopathy. J Diabetes Res 2018; 2018: 8546423. doi: 10.1155/2018/8546423

37. Zhou J, Zhou S. Inflammation: Therapeutic targets for diabetic neuropathy. Mol Neurobiol 2014; 49: 536-546. doi: 10.1007/s12035013-8537-0

38. Russell MA, Morgan NG. The impact of anti-inflammatory cytokines on the pancreatic $\beta$-cell. Islets 2014; 6: e950547. doi: 10.4161/19382014.2014.950547

39. Manzoor F, Johnson MC, Li C, et al. $\beta$-cell-specific IL-35 therapy suppresses ongoing autoimmune diabetes in NOD mice. Eur J Immunol 2017; 47: 144-154. doi: 10.1002/eji.20164649340.

40. Bettini M, Castellaw AH, Lennon GP, et al. Prevention of autoimmune diabetes by ectopic pancreatic $\beta$-cell expression of interleukin-35. Diabetes 2012; 61: 1519-1526. doi: 10.2337/db11-0784

41. Moustafa PE, Abdelkader NF, El Awdan SA, et al. Extracellular Matrix Remodeling and Modulation of Inflammation and Oxidative Stress by Sulforaphane in Experimental Diabetic Peripheral Neuropathy. Inflammation 2018; 41: 1460-1476. doi: 10.1007/s10753018-0792-9

42. Chai M, Ji Q, Zhang H, et al. The Protective Effect of Interleukin-37 on Vascular Calcification and Atherosclerosis in Apolipoprotein E-Deficient Mice with Diabetes. J Interf Cytokine Res 2015; 35: 530539. doi: 10.1089/jir.2014.0212

43. Huang Y, Lin YZ, Shi Y, et al. IL-35: A potential target for the treatment of atherosclerosis. Pharmazie 2013; 68: 793-795.

44. Marek N, Myśliwiec M, Raczyńska K, et al. Increased spontaneous production of VEGF by CD4+T cells in type 1 diabetes. Clin Immunol 2010; 137: 261-270. doi: 10.1016/j.clim.2010.07.007

45. Chiarelli F, Spagnoli A, Basciani F, et al. Vascular endothelial growth factor (VEGF) in children, adolescents and young adults with type 1 diabetes mellitus: Relation to glycaemic control and microvascular complications. Diabet Med 2000; 17: 650-656.

46. Myśliwiec M, Balcerska A, Zorena $K$, et al. The role of vascular endothelial growth factor, tumor necrosis factor alpha and interleukin-6 in pathogenesis of diabetic retinopathy. Diabetes Res Clin Pract 2008; 79: 141-146. doi: 10.1016/j.diabres.2007.07.011

47. Zorena K, Myśliwska J, Myśliwiec M, et al. Modulatory factors responsible for neoangiogenesis in young patients with long-standing diabetes mellitus type 1. Recent Pat Endocr Metab Immune Drug Discov 2009; 3: 144-149.

48. Zorena K, Myśliwska J, Myśliwiec M, et al. Interleukin-12, vascular endothelial growth factor and tumor necrosis factor-alpha in the process of neoangiogenesis of diabetic retinopathy in children. Klin Oczna 2007; 109: 155-159.
49. Quattrini C, Jeziorska M, Boulton AJM, et al. Reduced vascular endothelial growth factor expression and intra-epidermal nerve fiber loss in human diabetic neuropathy. Diabetes Care 2008; 31: 140145. doi: $10.2337 / \mathrm{dc} 07-1556$

50. Schratzberger P, Walter DH, Rittig K, et al. Reversal of experimental diabetic neuropathy by VEGF gene transfer. J Clin Invest 2001; 107: 1083-1092. doi: 10.1172/JCl12188

51. Sasso FC, Torella D, Carbonara O, et al. Increased vascular endothelial growth factor expression but impaired vascular endothelial growth factor receptor signaling in the myocardium of type 2 diabetic patients with chronic coronary heart disease. J Am Coll Cardiol 2005; 46: 827-834. doi: 10.1016/j.jacc.2005.06.007

52. Gordon KJ, Blobe GC. Role of transforming growth factor- $\beta$ superfamily signaling pathways in human disease. Biochim Biophys Acta Mol Basis Dis 2008; 1782:197-228. doi:10.1016/j.bbadis.2008.01.006

53. Zorena K, Raczyńska D, Wiśniewski P, et al. Relationship between serum transforming growth factor $\beta 1$ concentrations and the duration of type 1 diabetes mellitus in children and adolescents. Mediators Inflamm 2013; 2013: 849457. doi: 10.1155/2013/849457

54. Zorena K, Malinowska E, Raczyńska D, et al. Serum concentrations of transforming growth factor-beta 1 in predicting the occurrence of diabetic retinopathy in juvenile patients with type 1 diabetes mellitus. J Diabetes Res 2013; 2013: 614908. doi: 10.1155/2013/614908

55. Ziyadeh FN, Hoffman BB, Han DC, et al. Long-term prevention of renal insufficiency, excess matrix gene expression, and glomerular mesangial matrix expansion by treatment with monoclonal and antitransforming growth factor- $\beta$ antibody in $\mathrm{db} / \mathrm{db}$ diabetic mice. Proc Natl Acad Sci U S A 2000; 97: 8015-8020. doi: 10.1073/ pnas. 120055097

56. Voelker J, Berg PH, Sheetz M, et al. Anti-TGF- $\beta 1$ Antibody Therapy in Patients with Diabetic Nephropathy. J Am Soc Nephrol 2017; 28: 953-962. doi: 10.1681/ASN.2015111230.

57. Singh NN, Ramji DP. The role of transforming growth factor- $\beta$ in atherosclerosis. Cytokine Growth Factor Rev 2006; 17: 487-499. doi: 10.1016/j.cytogfr.2006.09.002

58. Uluçay S, Çam FS, Batır MB, et al. A novel association between TGF $\beta 1$ and ADAMTS 4 in coronary artery disease: A new potential mechanism in the progression of atherosclerosis and diabetes. Anadolu Kardiyol Derg 2015; 15: 823-829. doi: 10.5152/akd.2014.5762

59. Wang H, Li J, Fu X, et al. Effect of simvastatin on expression of VEGF and TGF- $\beta 1$ in atherosclerotic animal model of type 2 diabetes mellitus. Exp Ther Med 2018; 16: 2889-2894. doi: 10.3892/ etm.2018.6583

60. Yang SN, Burch ML, Tannock LR, et al. Transforming growth factor $\beta$ regulation of proteoglycan synthesis in vascular smooth muscle: Contribution to lipid binding and accelerated atherosclerosis in diabetes. J Diabetes 2010; 2: 233-242. doi: 10.1111/j.17530407.2010.00089.x

61. Vaidya VS, Niewczas MA, Ficociello LH, et al. Regression of microalbuminuria in type 1 diabetes is associated with lower levels of urinary tubular injury biomarkers, kidney injury molecule-1, and $\mathrm{N}$-acetyl- $\beta$-D-glucosaminidase. Kidney Int 2010; 79: 464-470. doi: 10.1038/ki.2010.404

62. Choi MS, Jun JE, Kim G, et al. The Association between Urinary N-Acetyl-B-D-Glucosaminidase and Cardiovascular Autonomic 
Neuropathy in Patients with Diabetes. Diabetes 2018; 67 (suppl. 1): 572. doi: https://doi.org/10.2337/db18-572-P

63. Lee $\mathrm{M}$, Hong $\mathrm{N}$, Lee $\mathrm{YH}$, et al. Elevated $\mathrm{N}$-acetyl- $\beta$-Dglucosaminidase, a urinary tubular damage marker, is a significant predictor of carotid artery atherosclerosis in type 1 diabetes, independent of albuminuria: A cross-sectional study. J Diabetes Complications 2018; 32: 777-783. doi: 10.1016/j.jdiacomp.2018.05.019

64. Kim SR, Lee YH, Lee SG, et al. The renal tubular damage marker urinary $\mathrm{N}$-acetyl- $\beta$-d-glucosaminidase may be more closely associated with early detection of atherosclerosis than the glomerular damage marker albuminuria in patients with type 2 diabetes. Cardiovasc Diabetol 2017; 16: 6. doi: 10.1186/s12933-017-0497-7

65. Glowinska B, Urban M, Peczynska J, et al. Soluble adhesion molecules (sICAM-1, sVCAM-1) and selectins (sE selectin, SP selectin, sL selectin) levels in children and adolescents with obesity, hypertension, and diabetes. Metabolism 2005; 33: 599-606. doi: 10.1016/j.metabol.2005.03.004

66. Fathollahi A, Massoud A, Amirzargar AA, et al. sICAM-1, sVCAM-1 and sE-Selectin Levels in Type 1 Diabetes. Fetal Pediatr Pathol 2018; 37: 69-73. doi: 10.1080/15513815.2017.1405467

67. Hoffman RP, Dye AS, Huang $H$, et al. Glycemic variability predicts inflammation in adolescents with type 1 diabetes. J Pediatr Endocrinol Metab 2016; 29: 1129-1133. doi: 10.1515/jpem-2016-0139

68. Meleth AD, Agrón E, Chan CC, et al. Serum inflammatory markers in diabetic retinopathy. Invest Ophthalmol Vis Sci 2005; 46: 42954301. doi: 10.1167/iovs.04-1057

69. Roy MS, Janal MN, Crosby J, et al. Markers of endothelial dysfunction and inflammation predict progression of diabetic nephropathy in African Americans with type 1 diabetes. Kidney Int 2015; 87 427-433. doi: 10.1038/ki.2014.212

70. Jude EB, Douglas JT, Anderson SG, et al. Circulating cellular adhesion molecules ICAM-1, VCAM-1, P- and E-selectin in the prediction of cardiovascular disease in diabetes mellitus. Eur J Intern Med 2002; 13: 185-189.

71. Blum A, Pastukh N, Socea D, et al. Levels of adhesion molecules in peripheral blood correlat with stages of diabetic retinopathy and may serve as bio markers for microvascular complications. Cytokine 2018; 106: 76-79. doi: 10.1016/j.cyto.2017.10.014
72. Soedamah-Muthu SS, Chaturvedi N, Schalkwijk CG, et al. Soluble vascular cell adhesion molecule-1 and soluble E-selectin are associated with micro- and macrovascular complications in Type 1 diabetic patients. J Diabetes Complications 2006; 20: 188-195. doi: 10.1016/j.jdiacomp.2005.06.005

73. Jude EB, Abbott CA, Young MJ, et al. The potential role of cell adhesion molecules in the pathogenesis of diabetic neuropathy. Diabetologia 1998; 41: 330-336. doi: 10.1007/s001250050911

74. Baker NL, Hunt KJ, Stevens DR, et al. Association between inflammatory markers and progression to kidney dysfunction: Examining different assessment windows in patients with type 1 diabetes. Diabetes Care 2018; 41: 128-135. doi: 10.2337/dc17-0867

75. Goldberg RB. Cytokine and cytokine-like inflammation markers, endothelial dysfunction, and imbalanced coagulation in development of diabetes and its complications. J Clin Endocrinol Metab 2009; 94: 3171-3182. doi: 10.1210/jc.2008-2534

76. Glowinska-Olszewska B, Urban M, Tolwinska J, et al. Correlation analysis between biochemical and biophysical markers of endothelium damage in children with diabetes type 1. Pediatr Endocrinol Diabetes Metab 2005; 11: 221-227. doi: 10.1210/jc.2008-2534.

77. Boulbou MS, Koukoulis GN, Vasiou KG, et al. Increased soluble E-selectin levels in type 2 diabetic patients with peripheral arterial disease. Int Angiol 2004; 23: 18-24.

78. Lopes-Virella MF, Baker NL, Hunt KJ, et al. Baseline markers of inflammation are associated with progression to macroalbuminuria in type 1 diabetic subjects. Diabetes Care 2013; 36: 2317-2323. doi: 10.2337/dc12-2521

79. Kaul K, Hodgkinson A, Tarr JM, et al. Is inflammation a common retinal-renal-nerve pathogenic link in diabetes? Curr Diabetes Rev 2010; 6: 294-303

80. Sasongko MB, Wong TY, Jenkins AJ, et al. Circulating markers of inflammation and endothelial function, and their relationship to diabetic retinopathy. Diabet Med J Br Diabet Assoc 2015; 32: 686-691. doi: 10.1111/dme.12640

81. Madonna R, Balistreri CR, Geng YJ, et al. Diabetic microangiopathy: Pathogenetic insights and novel therapeutic approaches. Vascul Pharmacol 2017; 90: 1-7. doi: 10.1016/j.vph.2017.01.004 